\title{
Balloon Angioplasty Enhances the Expression of Angiotensin II AT, Receptors in Neointima of Rat Aorta
}

\author{
Mohan Viswanathan, Christer Strömberg, Alicia Seltzer, and Juan M. Saavedra \\ Section on Pharmacology, Laboratory of Clinical Science, \\ National Institute of Mental Health, National Institutes of Health, Bethesda, Maryland 20892
}

\begin{abstract}
Angiotensin II is a vasoactive peptide and may act as a growth factor in vascular smooth muscle cells. Experimental injury of the rat aorta causes rapid migration of medial smooth muscle cells and their proliferation resulting in the formation of neointima. We have examined, using quantitative autoradiography, the expression of angiotensin II receptor subtypes $\mathrm{AT}_{1}$ and $\mathrm{AT}_{2}$, and angiotensin-converting enzyme, in the neointima formed in the rat thoracic aorta $15 \mathrm{~d}$ after balloon-catheter injury. In contrast to the normal aortic wall, which contained both $\mathrm{AT}_{1}$ and $\mathrm{AT}_{2}$ receptors $(80 \%$ and $20 \%$, respectively), neointimal cells expressed almost exclusively angiotensin II $\mathrm{AT}_{1}$ receptors. The apparent number of these receptors was fourfold higher in the neointima compared to that in the normal aortic wall. The affinities of the neointimal receptors to angiotensin II or to the $\mathrm{AT}_{1}$ receptor antagonist, losartan, were not different from those in the normal aortic wall. Angiotensin-converting enzyme binding in the neointima was not different from that in the media of the uninjured aorta. Our data suggest that angiotensin II $\mathbf{A T}_{1}$ receptors may have a significant role in injury-induced vascular smooth muscle proliferation and migration. (J. Clin. Invest. 1992. 90:1707-1712.) Key words: angiotensin II • angiotensin-converting enzyme $\bullet$ angiotensin receptor subtypes • growth • vascular smooth muscle
\end{abstract}

\section{Introduction}

Accumulation of neointimal smooth muscle cells, resulting from medial smooth muscle proliferation and migration in response to vascular injury, is believed to be one of the main events in the initiation of atherosclerosis $(1,2)$. Growth factors originating from platelets and macrophages adhering to the damaged vessel wall as well as factors secreted from endothelial and smooth muscle cells in the vessel wall are thought to play an active role in these processes (3). However, the mechanism by which various components initiate and sustain the replication of vascular smooth muscle leading to the formation of neointima after vascular injury is poorly understood.

One of the potent vasoactive peptides that may also function as a growth factor in the vasculature is angiotensin II (4,

Address reprint requests to Dr. Viswanathan, Section on Pharmacology, Laboratory of Clinical Science, Buliding 10, Room 2D-45, National Institute of Mental Health, 9000 Rockville Pike, Bethesda, MD 20892.

Received for publication 22 April 1992 and in revised form $14 \mathrm{Au}$ gust 1992.

J. Clin. Invest.

(C) The American Society for Clinical Investigation, Inc. $0021-9738 / 92 / 11 / 1707 / 06 \quad \$ 2.00$

Volume 90, November 1992, 1707-1712
5). Angiotensin II is also generated locally in the vascular wall (6), in that most of the components of the renin-angiotensin system are present in cultured vascular smooth muscle cells (4) and the vascular wall $(7,8)$. Recent findings that angiotensinconverting enzyme $(\mathrm{ACE})^{1}$ inhibition significantly reduces neointimal formation (9), and that angiotensin II stimulates smooth muscle proliferation in the injured arterial wall (10) underscore the likelihood that angiotensin II is a potential contributor to the formation of neointima.

Angiotensin II regulates vascular contractility through stimulation of specific receptors located in smooth muscle cells (7). Angiotensin II receptors have been classified recently into $\mathrm{AT}_{1}$ and $\mathrm{AT}_{2}$ subtypes, based on their affinities to peptidic and nonpeptidic ligands and by their differential sensitivities to dithiothreitol (11). $\mathrm{AT}_{1}$ receptors in the vasculature mediate vasoconstriction $(12,13)$, and until recently it was believed that arterial angiotensin II receptors were exclusively $\mathrm{AT}_{1}$. However, it has now been demonstrated that the rat aorta contains both $\mathrm{AT}_{1}$ and $\mathrm{AT}_{2}$ subtypes $(14,15)$. Further, it was reported that the proportion of $\mathrm{AT}_{2}$ receptors was markedly higher in the aorta of fetal and young rats (14), suggestive of a function for these receptors during vascular growth and development. The study of angiotensin II receptors and of the angiotensin II-forming enzyme, ACE, after vascular injury, may provide valuable information as to the contribution of the renin-angiotensin system to the arterial response to injury. We have used a well-characterized model of injury-induced vascular smooth muscle proliferation in adult rats $(16,17)$, to examine angiotensin II receptor subtypes and ACE expressed by neointimal cells. We report that neointimal cells express almost exclusively $\mathrm{AT}_{1}$ receptors and that their expression is higher when compared to those in the normal aortic wall.

\section{Methods}

Animals and preparation of tissue. Male Sprague-Dawley rats weighing 300-350 g (Zivic-Miller Laboratories, Inc., Zelienople, PA) were used in the study. In order to perform angioplasty of the thoracic aorta, rats were anesthetized i.m. with a mixture of ketamine $(100 \mathrm{mg} / \mathrm{kg})$ and acepromazine $(10 \mathrm{mg} / \mathrm{kg})$. An arterial embolectomy (balloon) catheter (2F-Fogarty, Baxter Healthcare Corp., Santa Ana, CA) was introduced via the left common carotid artery into the thoracic aorta down to the level of the diaphragm, inflated, and pulled back. This procedure was repeated three times. Sham-operated animals were anesthetized and as in the case of the catheterized animals, the left carotid artery was ligated. $15 \mathrm{~d}$ after surgery, rats were killed by decapitation and $2-\mathrm{cm}-$ long segments of the thoracic aorta were removed and frozen at $-30^{\circ} \mathrm{C}$. In a separate experiment, rats were anesthetized with halothane, and the thoracic aorta and left common carotid artery were injured using a balloon-catheter introduced through the right iliac artery. These ani-

1. Abbreviations used in this paper: $\mathrm{ACE}$, angiotensin-converting enzyme; PDGF, platelet-derived growth factor. 

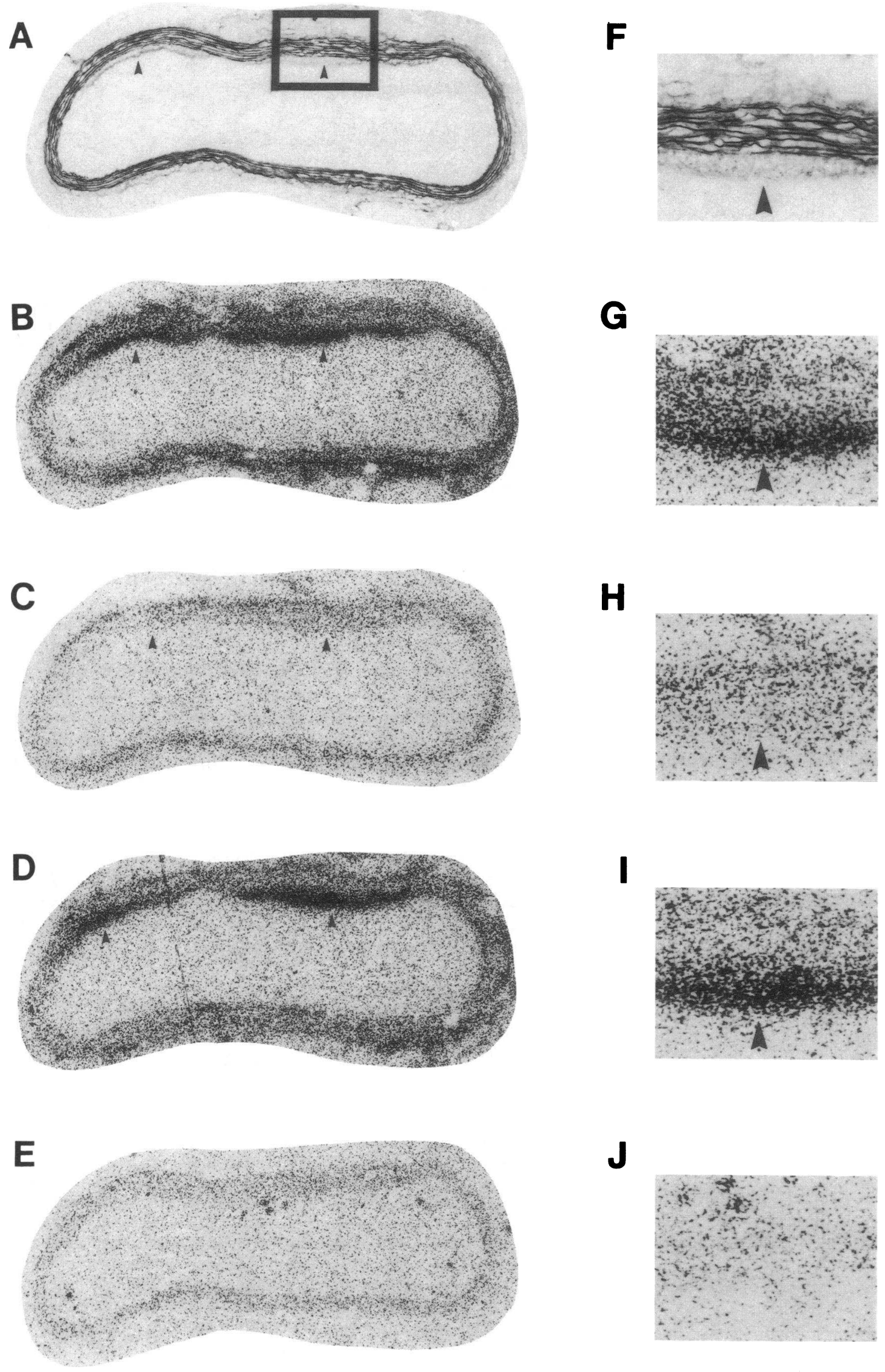

Figure 1. Autoradiography of angiotensin II receptors in rat aorta injured by balloon catheter. $(A-E)$ Consecutive sections of aorta with arrowheads pointing to neointima $(\times 37)$. $(F-J)$ Enlarged $(\times 100)$ view of area marked in $A$, from corresponding sections on their left. Arrowhead 
mals were killed by decapitation $8 \mathrm{~d}$ after surgery and segments of injured thoracic aorta and left common carotid artery, and intact right common carotid artery were removed and frozen as before.

The tissues were kept frozen at $-70^{\circ} \mathrm{C}$. Cross sections $(16 \mu \mathrm{m})$ of the vessels were cut in a cryostat at $-17^{\circ} \mathrm{C}$, thaw mounted on gelatincoated glass slides, and dried overnight in a desiccator at $4^{\circ} \mathrm{C}$.

Angiotensin receptor binding assay. The binding conditions used to study angiotensin II receptors have been described before (14). The angiotensin II agonist, ${ }^{125} \mathrm{I}$-[Sar ${ }^{1}$ ] angiotensin II (Peninsula Laboratories, Inc., Belmont, CA; iodinated by New England Nuclear, Wilmington, $\mathrm{DE}$; sp act $2,200 \mathrm{Ci} / \mathrm{mmol}$ ) was used as the ligand. Tissue sections were preincubated for $15 \mathrm{~min}$ in $10 \mathrm{mM}$ phosphate buffer ( $\mathrm{pH} \mathrm{7.4)}$ containing $120 \mathrm{mM} \mathrm{NaCl}, 5 \mathrm{mM} \mathrm{Na}_{2}$ EDTA, $0.005 \%$ bacitracin (Sigma Chemical Co., St. Louis, MO), and $0.2 \%$ proteinase-free bovine serum albumin (Sigma Chemical Co.), followed by incubation for $120 \mathrm{~min}$, at $22^{\circ} \mathrm{C}$, in fresh buffer containing the appropriate concentration of the ligand. After incubation, the sections were washed four times, for $1 \mathrm{~min}$ each, in fresh ice-cold $50 \mathrm{mM}$ Tris- $\mathrm{HCl}$ buffer ( $\mathrm{pH} \mathrm{7.6)}$, followed by 30 $\mathrm{s}$ in distilled water at $0^{\circ} \mathrm{C}$.

To characterize angiotensin II receptor subtypes, consecutive sections were incubated with [ ${ }^{125} \mathrm{I}$ ] [Sar ${ }^{1}$ ]angiotensin II $\left(5 \times 10^{-10} \mathrm{M}\right)$ and increasing concentrations of angiotensin II, $\mathrm{AT}_{1}$ antagonist losartan potassium (DuP 753; 2- $n$-butyl-4-chloro-5-hydroxymethyl-1[2'(1H-tetrazol-5-yl) biphenyl-4-yl-methyl]imidazole, potassium salt, from DuPont Co., Wilmington, DE) or $\mathrm{AT}_{2}$ competitor PD 123177 (1-(4-amino-3-methylphenyl)methyl-5-diphenylacetyl-4,5,6,7-tetrahydro-1H-imidazo[4,5-c]pyridine-6-carboxylic acid-2 $\mathrm{HCl}$, from Parke Davis, Ann Arbor, MI).

Sections were dried after washing and exposed to Hyperfilm- $\left[{ }^{3} \mathrm{H}\right]$ (Amersham Corp., Arlington Heights, IL), along with $16-\mu \mathrm{m}$ sections of ${ }^{125}$ I-labeled Micro-scale standards (Amersham Corp.). Films were developed in Kodak D-19 developer (Eastman Kodak Co., Rochester, $\mathrm{NY}$ ) for 4 min at $0^{\circ} \mathrm{C}$, and fixed in Kodak rapid fixer (with hardener) for $4 \mathrm{~min}$ at $22^{\circ} \mathrm{C}$, and rinsed in water for $10 \mathrm{~min}$. Optical density and disintegrations per minute per milligram of plastic values of the standards were used to generate a standard curve by nonlinear fitting using the computerized RAS-R 1000 Research Analysis System (Loats Associates, Westminster, MD). Based on the experimental relation between plastic and protein standards (18), disintegrations per minute per milligram of protein values were obtained. Mean optical densities measured from the autoradiograms were then transformed to corresponding values of disintegrations per minute per milligram of protein, and by correcting for the specific activity of the ligand, values of femtomoles per milligram of protein values were obtained.

In the first experiment, binding was quantified separately in the neointima and in the media of balloon-injured aorta as well as in the media of intact aorta from sham-operated animals. In the second experiment, binding was quantified in the media and neointima present in the aorta and left carotid artery, and in the media of the intact right carotid artery.

Binding in consecutive sections, from the aorta of five different animals, which were incubated with ${ }^{125} \mathrm{I}$-[ $\left.\mathrm{Sar}^{1}\right]$ angiotensin II (5 $\left.\times 10^{-10} \mathrm{M}\right)$ and increasing concentrations of angiotensin II, AT ${ }_{1}$ antagonist losartan, or $\mathrm{AT}_{2}$ competitor PD 123177, was quantified separately. Competition curves were generated from these values using the Inplot program (GraphPad, San Diego, CA) and used for the calculation of $\mathrm{IC}_{50}$ values. The apparent number of $\mathrm{AT}_{1}$ receptors was determined as the specific binding not displaced by $10^{-5} \mathrm{M}$ PD 123177 or $10^{-7}$ M CGP $42112 \mathrm{~A}$ (nicotinic acid-Tyr- $N$-benzyloxycarbonyl-ArgLys-His-Pro-Ile-OH; CIBA-Geigy, Basel ), whereas that of $\mathrm{AT}_{2}$ recep- tors was determined as the specific binding not displaced by $10^{-5} \mathrm{M}$ losartan.

Autoradiography of $A C E$. We measured the binding of radiolabeled, specific ACE inhibitor 351A to ACE. The compound 351A was iodinated using the chloramine-T method ( $\mathrm{sp}$ act $2,200 \mathrm{Ci} / \mathrm{mmol}$; New England Nuclear) (19). The autoradiographic quantification of binding of ${ }^{125} \mathrm{I}-351 \mathrm{~A}$ to ACE correlates well with the activity as well as the quantity of the enzyme as determined by immunohistochemistry (19). Tissue sections were preincubated for $30 \mathrm{~min}$ in $50 \mathrm{mM}$ Tris buffer, pH 7.4, at $22^{\circ} \mathrm{C}$, containing $100 \mathrm{mM} \mathrm{NaCl}$. Sections assigned for nonspecific binding were preincubated in the same buffer in the presence of $10^{-7} \mathrm{M}$ MK521 (19). After preincubation, the sections were incubated with $2 \mathrm{nM}{ }^{125} \mathrm{I}-351 \mathrm{~A}$ in the same buffer, for $2 \mathrm{~h}$, at $22^{\circ} \mathrm{C}$. Nonspecific binding was determined in the presence of $2 \times 10^{-6}$ M MK521. After incubation, the sections were washed four times, 1

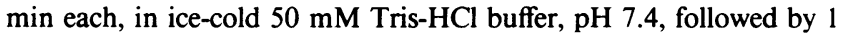
min in cold distilled water. Sections were exposed, developed, and quantified as described above for angiotensin II receptor binding.

\section{Results}

Histological examination of the injured aorta revealed marked neointimal formation, which showed the characteristic pattern of being localized only to one side of the vessel (16). The concentration of angiotensin II receptors was approximately four times higher in the neointima than in the media of the injured aortic wall or that in the media of intact aorta from sham-operated animals (Figs. 1 and 2). In the injured aorta, the high expression of angiotensin II receptors was localized specifically to the neointimal cells (Fig. 2). All of this increase was due to $\mathrm{AT}_{1}$ receptors. $\mathrm{AT}_{2}$ receptors in the neointima comprised only $\sim 3 \%$ of the total binding, compared with $20 \%$ in the uninjured aortic wall (Fig. 2). Similar results were obtained in a separate experiment in which carotid artery as well as aorta were examined $8 \mathrm{~d}$ after balloon-injury (Table I). Therefore it appears that the enhanced expression of $\mathrm{AT}_{1}$ receptors in the neointima is present, in carotid artery as well as in the aorta, as early as $8 \mathrm{~d}$ after injury.

Angiotensin II receptors in the neointima and in the aortic wall had similar affinities to angiotensin II and losartan $\left(\mathrm{IC}_{50}\right.$ for angiotensin II, $4.0 \times 10^{-9} \mathrm{M}$ and $1.8 \times 10^{-9} \mathrm{M}$; for losartan, $1.1 \times 10^{-7} \mathrm{M}$ and $0.6 \times 10^{-7} \mathrm{M}$ in neointima and uninjured aortic wall, respectively) (Fig. 3).

Specific binding of ${ }^{125} \mathrm{I}-351 \mathrm{~A}$ to ACE was localized in the aortic wall with distinctly higher concentration in the adventitial and endothelial layers compared to that in the media (Fig. 4). $15 \mathrm{~d}$ after injury, binding to ACE in the neointima was not different from that in the media of the aorta from sham-operated animals (Fig. 5).

\section{Discussion}

Migration of medial smooth muscle cells into the intima and their replication are characteristic features of neointimal formation after endothelial denudation (20). Specific factors responsible for these processes are only poorly understood. It is

points to neointima. ( $A$ and $F$ ) Sections stained with hematoxylin and eosin. ( $B$ and $G$ ) Sections showing binding after incubation with $5 \times 10^{-10}$ $\mathrm{M}^{125} \mathrm{I}$-[ $\mathrm{Sar}^{1}$ ] angiotensin II (total binding). ( $C$ and $H$ ) Section incubated as in $B$, in the presence of $10^{-5} \mathrm{M}$ losartan. ( $D$ and $\left.I\right)$ Section incubated as in $B$, in the presence of $10^{-5} \mathrm{M}$ PD 123177. ( $E$ and $J$ ) Sections incubated as in $B$, in the presence of $5 \times 10^{-6} \mathrm{M}$ angiotensin II (nonspecific binding). 


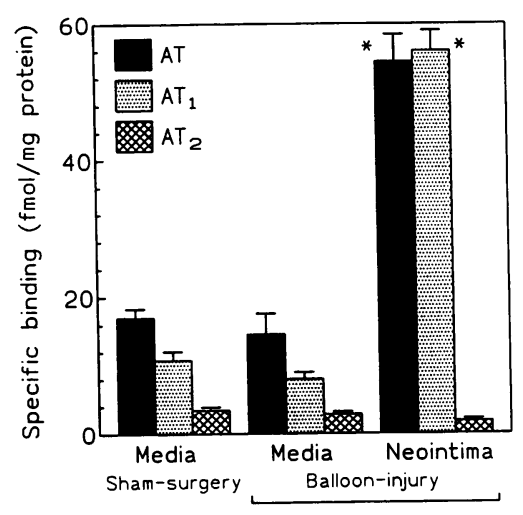

Figure 2. Apparent amount of angiotensin II receptor subtypes in the media of aorta from sham-operated and balloon-catheterized rats, and in the neointima. AT: specific ${ }^{125} \mathrm{I}-\left[\mathrm{Sar}^{1}\right]-$ angiotensin II binding. $\mathrm{AT}_{1}$ and $\mathrm{AT}_{2}$ : specific binding not displaced by $10^{-5} \mathrm{M}$ PD 123177 or losartan, respectively. Values are mean \pm SEM obtained from five rats, measured individually. Angiotensin II receptors $(A T)$ in the neointima were significantly higher $\left({ }^{*} P<0.001\right.$; one-way ANOVA followed by Bonferroni test) than in the aortic media of either shamoperated or balloon-catheterized rats, and this was due to increase in $\mathrm{AT}_{1}$ receptors.

currently believed that local tissue generation of angiotensin II may contribute to myointimal hyperplasia (21). We have demonstrated that neointima formed in injured rat aorta contains almost exclusively angiotensin $\mathrm{II}_{\mathrm{AT}}$ receptors. $\mathrm{AT}_{1}$ receptors are expressed severalfold higher than in the media of injured aorta or in the aortic media of sham-operated animals. This increase was already present $8 \mathrm{~d}$ after injury. Higher expression of $\mathrm{AT}_{1}$ receptors in the neointima was not limited to the aorta and occurred in the carotid artery as well. These findings along with the ones that angiotensin II stimulates neointimal smooth muscle proliferation (10) can be treated as evidence for an active role of the renin-angiotensin system in vascular smooth muscle replication.

Pharmacological treatments that interfere with the vascular renin-angiotensin system have been effective in suppressing injury-induced formation of neointima. There is recent evidence that in vivo treatment of balloon catheter injured rats with the angiotensin II $\mathrm{AT}_{1}$ receptor antagonist losartan significantly reduces neointimal formation $(22,23)$. Inhibition of

Table I. Angiotensin II Receptor Subtypes in Intact Right Carotid Artery and Injured Left Carotid Artery and Aorta, $8 d$ after Angioplasty

\begin{tabular}{|c|c|c|c|c|}
\hline & AT & $\mathrm{AT}_{1}$ & $\mathrm{AT}_{1}^{*}$ & $\mathrm{AT}_{2}$ \\
\hline & \multicolumn{4}{|c|}{$\mathrm{fmol} / \mathrm{mg}$ protein } \\
\hline \multicolumn{5}{|l|}{ Carotid artery } \\
\hline Right carotid (media) & $32 \pm 5$ & $27 \pm 2$ & $27 \pm 4$ & $1 \pm 0.3$ \\
\hline Left carotid (neointima) & $67 \pm 5^{\ddagger}$ & $63 \pm 2^{\ddagger}$ & $61 \pm 4^{\ddagger}$ & ND \\
\hline \multicolumn{5}{|l|}{ Aorta } \\
\hline Media & $12 \pm 1$ & $10 \pm 1$ & $10 \pm 1$ & $5 \pm 1$ \\
\hline Neointima & $26 \pm 3^{\ddagger}$ & $27 \pm 4^{\ddagger}$ & $28 \pm 3^{\ddagger}$ & $1 \pm 0.3$ \\
\hline
\end{tabular}

Values are means \pm SEM obtained from five rats, measured individually. AT, specific ${ }^{125} \mathrm{I}-\left[\mathrm{Sar}^{1}\right.$ ] angiotensin II binding; $\mathrm{AT}_{1}$ and $\mathrm{AT}_{2}$, specific binding not displaced by $10^{-5} \mathrm{M}$ PD 123177 or losartan, respectively. $\mathrm{AT}_{1}{ }^{*}$, specific binding not displaced by $10^{-7} \mathrm{M}$ CGP 42112A. ND, no detectable specific binding. Angiotensin II AT $\mathrm{Ar}_{1}$ receptors in the neointima were significantly $\left({ }^{\ddagger} P<0.01\right.$; unpaired $t$ test) higher than in the media of both carotid artery and aorta.

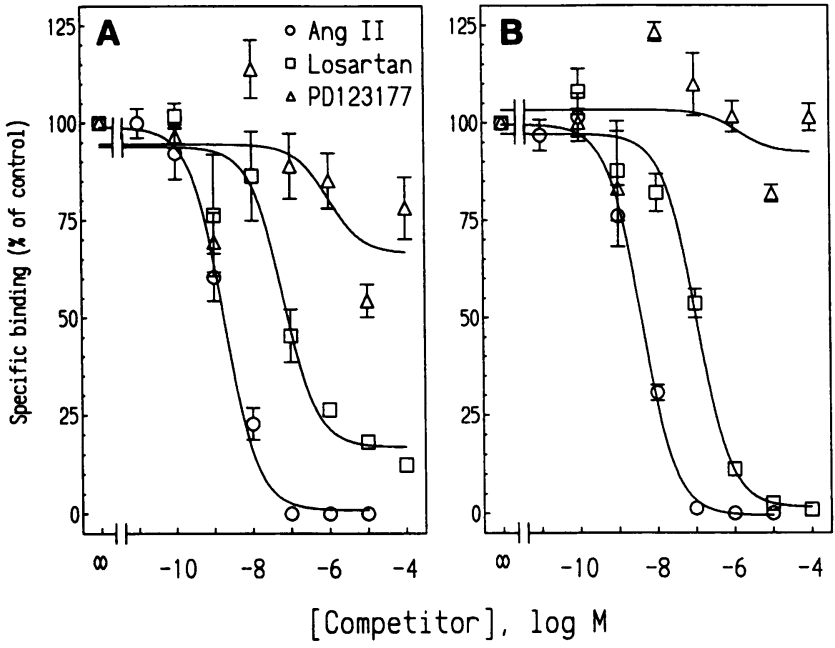

Figure 3. Competition of angiotensin II, losartan, and PD 123177 for specific binding in the $(A)$ uninjured aortic wall and $(B)$ neointima. Competition curves were obtained from consecutive sections of aorta, incubated in the presence of $5 \times 10^{-10} \mathrm{M}^{125} \mathrm{I}$-[ $\mathrm{Sar}^{1}$ ] angiotensin II and increasing concentrations of angiotensin II or angiotensin II receptor competitors, losartan and PD 123177. Results are means \pm SEM obtained from five rats, measured individually.

ACE with either cilazapril (9), captopril (22), or ramipril (24) has also been shown to be effective in inhibiting intimal thickening after balloon-catheter injury. Our finding that, $15 \mathrm{~d}$ after injury, there was no increase in ACE in the neointima may only indicate that the formation of angiotensin II was not raised in this tissue. In addition to the possibility that ACE inhibitors may act by suppressing the local generation of angiotensin II in the aortic wall, an alternate mechanism of action has been proposed recently $(25)$. The increased $A_{1}$ receptor expression in the neointima may in itself be sufficient to enhance the local smooth muscle proliferative effects of angiotensin II. Our results provide a direct basis for the observations that decreasing the formation of angiotensin II by ACE inhibitors $(9,22,24)$ or blocking angiotensin II $\mathrm{AT}_{1}$ receptors with the specific receptor antagonist, losartan $(22,23)$, are effective in inhibiting the formation of injury-induced neointima.

Growth factors responsible for vascular injury-induced intimal smooth muscle replication have only begun to be identified. Along with angiotensin II (10), platelet-derived growth factor (PDGF) (26-30) and basic fibroblast growth factor (31) are currently considered to be likely candidates. Several of these studies indicate that regulation of PDGF or its receptor expression would be of significance in the formation of neointima. Angiotensin II induces the expression of PDGF A-chain mRNA as well as PDGF in vascular smooth muscles in culture (32), which is not inhibited by ACE inhibition (33). However, in vivo administration of angiotensin II did not have a significant effect on PDGF A-chain mRNA expression in the rat aorta (34). These findings, along with our present findings that angiotensin $\mathrm{AT}_{1}$ receptor expression is markedly increased specifically in the neointimal cells, raise the interesting possibility of angiotensin II acting as a promoter of PDGF expression in the neointima.

Components of the extracellular matrix have been proposed to act as regulators of modulation or dedifferentiation of vascular smooth muscle (35-38) and thereby facilitate growth 

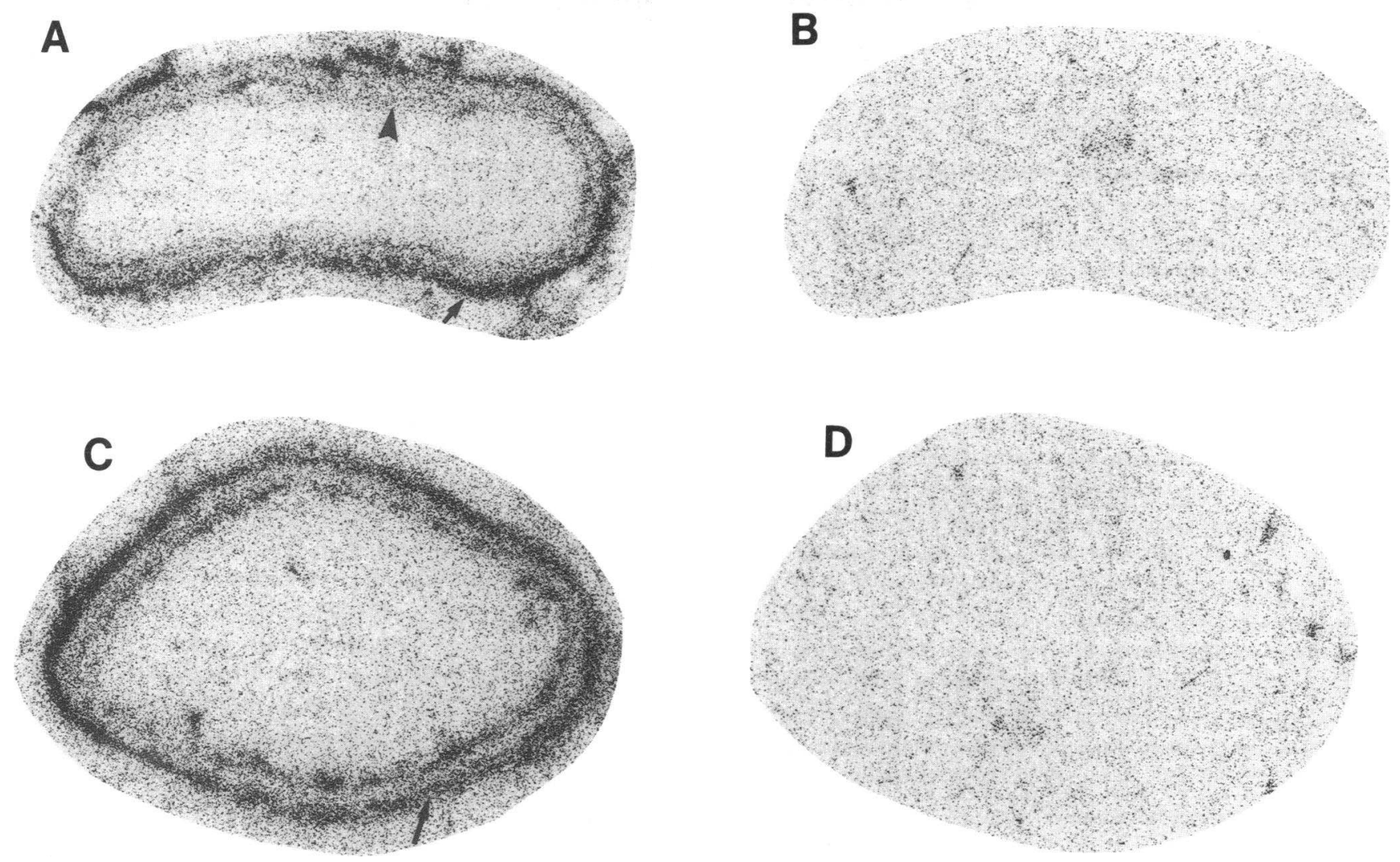

Figure 4. Autoradiographic localization of ACE in $(A)$ balloon-catheterized and $(C)$ uninjured rat aorta. $(A$ and $C)$ Sections incubated in the presence of the ACE inhibitor, ${ }^{125} \mathrm{I}-351 \mathrm{~A}$, as described in methods. ( $B$ and $D$ ) Consecutive sections to $A$ and $B$, respectively, incubated in the presence of ${ }^{125} \mathrm{I}-351 \mathrm{~A}$ and unlabeled MK 521 as described in methods (nonspecific binding). Arrowhead points to neointima that could be seen in Fig. $1 \mathrm{~A}$, and arrow to ACE localized to the adventitia $(\times 37)$.

(39). That angiotensin II is able to induce the expression of thrombospondin, an extracellular matrix glycopeptide, in vascular smooth muscle (40), suggests yet another pathway of action of angiotensin II to promote smooth muscle growth. Taken together, all of these findings indicate that the angiotensin II $\mathrm{AT}_{1}$ receptors expressed highly in the neointimal cells may also function to induce several factors such as PDGF and thrombospondin, which are of importance in the regulation of vascular smooth muscle replication and migration.

In conclusion, we have demonstrated, using quantitative autoradiography, that the expression of arterial angiotensin II

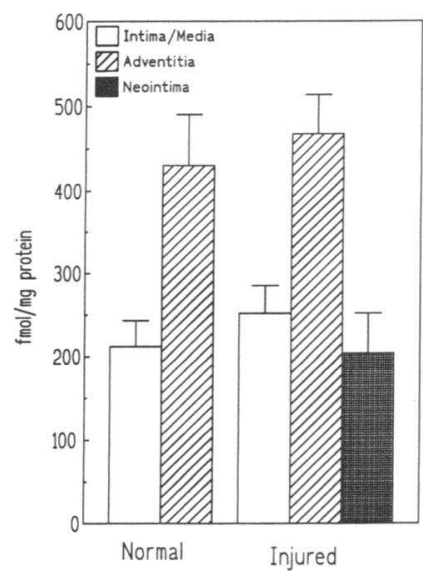

Figure 5. ACE binding, measured by autoradiography, in aorta from sham-operated (normal) and balloon-catheterized (injured) rats. Values are mean \pm SEM obtained from five rats, measured individually.
$\mathrm{AT}_{1}$ receptors is selectively and markedly increased in the neointima formed after balloon catheter-induced arterial injury. This finding supports the hypothesis of a role for angiotensin II in the arterial response to injury (21), and raises the possibility that angiotensin II $\mathrm{AT}_{1}$ receptors may have an important function in the migration and proliferation of neointimal smooth muscle cells. Therapeutic strategies involving a combination of $\mathrm{ACE}$ inhibition and angiotensin $\mathrm{AT}_{1}$ receptor blockade have the potential to be effective in the intervention of restenosis after angioplasty.

\section{Acknowledgments}

We would like to thank Dr. Ronald D. Smith from DuPont Experimental Station (Wilmington, DE) for his gift of losartan, Dr. David G. Taylor from Parke Davis (Ann Arbor, MI) for his gift of PD 123177, and Dr. M. de Gasparo from CIBA-Geigy (Basel) for his gift of CGP 42112A.

\section{References}

1. Ross, R. 1986. The pathogenesis of atheosclerosis: an update. N. Engl. J. Med. 314:488-500.

2. Schwartz, S. M., G. R. Campbell, and J. H. Campbell. 1986. Replication of smooth muscle cells in vascular disease. Circ. Res. 58:427-444.

3. Ross, R. 1991. Polypeptide growth factors and atherosclerosis. Trends Cardiovasc. Med. 1:277-282.

4. Dzau, V. J. 1984. Vascular renin-angiotensin: a possible autocrine or para- 
crine system in control of vascular function. J. Cardiovasc. Pharmacol. 6:S377S382.

5. Schelling, P., H. Fisher, and D. Ganten. 1991. Angiotensin and cell growth: a link to cardiovascular hypertrophy. J. Hypertens. 9:3-15.

6. Campbell, D. J. 1987. Circulating and tissue angiotensin systems. J. Clin. Invest. 79:1-6.

7. Dzau, V. J. 1986. Significance of the renin-angiotensin pathway. Hypertension. 8:553-559.

8. Wong, P. C., T. M. Reilly, and P. B. M. W. M. Timmermans. 1989. Effect of a monoclonal antibody to angiotensin II on hemodynamic responses to noradrenergic stimulation in pithed rats. Hypertension. 14:488-497.

9. Powell, J. S., J. P. Clozel, R. K. M. Müller, H. Kuhn, F. Hefti, M. Hosang, and H. R. Baumgartner. 1989. Inhibitors of angiotensin-converting enzyme prevent myointimal proliferation after vascular injury. Science (Wash. DC). 245:186-188.

10. Daemen, M. J. A. P., D. M. Lombardi, F. T. Bosman, and S. M. Schwartz. 1991. Angiotensin II induces smooth muscle cell proliferation in the normal and injured rat arterial wall. Circ. Res. 68:450-456.

11. Bumpus, F. M., K. J. Catt, A. T. Chiu, M. de Gasparo, T. Goodfriend, A. Husain, M. J. Peach, D. G. Taylor Jr., and P. B. M. W. M. Timmermans. 1991. Nomenclature for angiotensin receptors: a report of the nomenclature committee of the council for high blood pressure research. Hypertension. 17:720-721.

12. Wong, P. C., S. D. Hart, A. M. Zaspel, A. T. Chiu, R. J. Ardecky, R. D. Smith, and P. B. M. W. M. Timmermans. 1990. Functional studies of nonpeptide angiotensin II receptor subtype-specific ligands: DuP 753 (AII-1) and PD 123177 (AII-2). J. Pharmacol. Exp. Ther. 255:584-592.

13. Dudley, D. T., R. L. Panek, T. C. Major, G. H. Lu, R. S. Bruns, B. A. Klinkefus, J. C. Hodges, and R. E. Weishaar. 1990. Subclasses of angiotensin II binding sites and their functional significance. Mol. Pharmacol. 38:370-377.

14. Viswanathan, M., K. Tsutsumi, F. M. A. Correa, and J. M. Saavedra. 1991. Changes in the expression of angiotensin receptor subtypes in the rat aorta during development. Biochem. Biophys. Res. Commun. 179:1361-1367.

15. Chang, R. S., and V. J. Lotti. 1991. Angiotensin receptor subtypes in rat, rabbit and monkey tissues: relative distribution and species dependency. Life Sci. 49:1485-1490.

16. Haudenschild, C., and S. M. Schwartz. 1979. Endothelial regeneration. II. Restitution of endothelial continuity. Lab. Invest. 41:407-418.

17. Reidy, M. A. 1985. Biology of disease: a reassessment of endothelial injury and arterial lesion formation. Lab. Invest. 53:513-520.

18. Nazarali, A. J., J. S. Gutkind, and J. M. Saavedra. 1989. Calibration of ${ }^{125}$ I-polymer standards with ${ }^{125} \mathrm{I}$-brain paste standards for use in quantitative receptor autoradiography. J. Neurosci. Methods 30:247-253.

19. Correa, F. M. A., L. M. Plunkett, and J. M. Saavedra. 1986. Quantitative distribution of angiotensin-converting enzyme (kininase II) in discrete areas of the rat brain by autoradiography with computerized microdensitometry. Brain Res. 375:259-266.

20. Clowes, A. W., M. A. Reidy, and M. M. Clowes. 1983. Kinetics of cellular proliferation after arterial injury: 1 . Smooth muscle growth in the absence of endothelium. Lab. Invest. 49:327-333.

21. Dzau, V. J., G. H. Gibbons, and R. E. Pratt. 1991. Molecular mechanisms of vascular renin-angiotensin system in myointimal hyperplasia. Hypertension. 18:II-100-II-105.

22. Kauffman, R. F., J. S. Bean, K. M. Zimmerman, R. F. Brown, and M. I. Steinberg. 1991. Losartan, a nonpeptide angiotensin II (Ang II) receptor antagonist, inhibits neointima formation following balloon injury to rat carotid arteries. Life Sci. 49:PL223-PL228.

23. Osterrieder, W., R. K. M. Müller, J. S. Powell, J. P. Clozel, F. Hefti, and
H. R. Baumgartner. 1991. Role of angiotensin II in injury-induced neointima formation in rats. Hypertension. 18:II-60-II-64.

24. Capron, L., D. Heudes, A. Chajara, and P. Bruneval. 1991. Effect of ramipril, an inhibitor of angiotensin converting enzyme, on the response of rat thoracic aorta to injury with a balloon catheter. J. Cardiovasc. Pharmacol. 18:207-211.

25. Farhy, R. D., K. L. Ho, O. A. Carretero, and A. G. Scicli. 1992. Kinins mediate the antiproliferative effect of ramipril in rat carotid artery. Biochem. Biophys. Res. Commun. 182:283-288.

26. Ferns, G. A. A., E. W. Raines, K. H. Sprugel, A. S. Motani, M. A. Reidy, and R. Ross. 1991. Inhibition of neointimal smooth muscle accumulation after angioplasty by an antibody to PDGF. Science (Wash. DC). 253:1129-1132.

27. Barrett, T. B., and E. P. Benditt. 1988. Platelet-derived growth factor gene expression in human atherosclerotic plaques and normal artery wall. Proc. Natl. Acad. Sci. USA. 85:2810-2814.

28. Golden, M. A., Y. P. T. Au, T. R. Kirkman, J. N. Wilcox, E. W. Raines, R Ross, and A. W. Clowes. 1991. Platelet-derived growth factor activity and mRNA expression in healing vascular grafts in baboons. J. Clin. Invest. 87:406-414.

29. Majesky, M. W., M. A. Reidy, D. F. Bowen-Pope, C. E. Hart, J. N. Wilcox, and S. M. Schwartz. 1990. PDGF ligand and receptor gene expression during repair of arterial injury. J. Cell Biol. 111:2149-2158.

30. Libby, P., S. J. C. Warner, R. N. Salomon, and L. K. Birinyl. 1988. Production of platelet-derived growth-factor mitogen by smooth-muscle cells from human atheroma. N. Engl. J. Med. 318:1493-1498.

31. Lindner, V., D. A. Lappi, A. Baird, R. A. Majack, and M. A. Reidy. 1991. Role of basic fibroblast growth factor in vascular lesion formation. Circ. Res. 68:106-113.

32. Naftilan, A. J., R. E. Pratt, and V. J. Dzau. 1989. Induction of platelet-derived growth factor A-chain and c-myc gene expressions by angiotensin II in cultured rat vascular smooth muscle cells. J. Clin. Invest. 83:1419-1424.

33. Powell, J. S., R. K. M. Müller, M. Rouge, H. Kuhn, F. Hefti, and H. R. Baumgartner. 1991. The proliferative response to vascular injury is suppressed by angiotensin-converting enzyme inhibition. J. Cardiovasc. Pharmacol. 16:S42S49.

34. Majesky, M. W., M. J. A. P. Daemen, and S. M. Schwartz. 1990. $\alpha 1$ Adrenergic stimulation of platelet-derived growth factor A-chain gene expression in rat aorta. J. Biol. Chem. 265:1082-1088.

35. Kocher, O., O. Skalli, D. Cerutti, F. Gabbiani, and G. Gabbiani. 1985. Cytoskeletal features of rat aortic cells during development. Circ. Res. 56:829838.

36. Fager, G., G. K. Hansson, A. Gown, D. Larson, O. Skalli, and G. Bondgers. 1989. Human arterial smooth muscle cells in culture: Inverse relationship between proliferation and expression of contractile proteins. In Vitro Cell Dev. Biol. 25:511-520.

37. Wilcox, J., K. Smith, L. Williams, S. Schwartz, and D. Gordon. 1988. Platelet-derived growth-factor production in human atherosclerotic plaque by in situ hybridization. J. Clin. Invest. 82:1134-1144.

38. Gabbiani, G., O. Kocher, W. S. Bloom, J. Vandekerckhove, and K. Weber. 1984. Actin expression in smooth muscle cells of rat aortic intimal thickening, human atheromatous plaque, and cultured rat aortic media. J. Clin. In vest. 73:148-152.

39. Scott-Burden, T., and F. R. Bühler. 1988. Regulation of smooth muscle proliferative phenotype by heparinoid-matrix interactions. Trends Pharmacol. Sci. 9:94-98.

40. Scott-Burden, T., T. J. Resink, A. W. A. Hahn, and F. R. Bühler. 1990. Induction of thrombospondin expression in vascular smooth muscle cells by angiotensin II. J. Cardiovasc. Pharmacol. 16:S17-S20. 